\title{
АВТОРСЬКА МОДЕЛЬ ФОРМУВАННЯ ІНФОРМАТИЧНОЇ КОМПЕТЕНТНОСТІ В МАЙБУТНІХ ПЕДАГОГІВ ПРОФЕСІЙНОГО НАВЧАННЯ
}

У статті представлено результати наукового дослідження процесу формування інформатичної компетентності в майбутніх спеціалістів, зокрема педагогів професійного навчання в закладах вищої освіти (ЗВО), відтворено особливості об'єкта дослідження на прикладі розробленої педагогічної моделі та встановлено взаємозв'язки між системними елементами процесу формування інформатичної компетентності. Основою статті євисвітлення думок значної кількості науковціьв щзоо педагогічної моделі, яка показуе взаємозв'язки між елементами досліджуваного процесу та їхню взаємозалежність, а також надає можливість з'ясувати й виокремити важливі характеристики аналізованого об'єкта і його функціювання.

Піл час аналізу науково-педагогічної літератури було визначено складові частини педагогічної моделі формування інформатичної компетентності майбутніх педагогів професійного навчання та виокремлено педагогічні умови й блоки педагогічної моделі. 3 огляду на теоретичний аналіз, можна сказати, щьо педагогічна модель має такі взаємопов'язані між собою блоки: цุільовий - містить мету, завдання, підходи (системний, синергетичний, компетентнісний, діяльнісний, інтердисцииплінарний, акмеологічний) й принциипи (загальнодидактичні, специфічні); змістовий - включае компоненти інформатичної компетентності (мотиваційно-иіннісний, когнітивний, діяльнісно-професійний, оцінювально-рефлексивний), зміст, етапи, форми $і$ методи навчання; результативнооцінювальний - включае критерії, показники й рівні, які сприяють отриханню конкретного результату, тобто сформованості інформатичної компетентності майбутніх педагогів професійного навчання під час підготовки у ЗВО.

На основі аналізу науково-педагогічної літератури розроблена педагогічна модель, яка є цุілком працездатною й спрямована на формування інформатичної компетентності в майбутніх педагогів професійного навчання. Також вона $\epsilon$ поштовхом до розробки організаційно-методичного забезпечення й спецькурсу запропонованої моделі формування інформатичної компетентності майбутніх педагогів професійного навчання nід час підготовки в закладах вищої освіти.

Ключові слова: компетентність, інформатична компетентність, компонент, модель, педагогічна модель, освіта, критерії, вища освіта, педагог професійного навчання.

Постановка проблеми. Нові тенденції в розвитку европейського суспільства, повсякденні зміни в інформаційному середовищі кожної держави вимагають від освітян суттєвих змін у науково-освітньому просторі закладів освіти, зокрема закладів вищої освіти (3ВО). Однією з основних проблем професійної (професійно-технічної) освіти є якісна підготовка інформатично грамотних спеціалістів для всіх сфер діяльності людини.

Зазначена проблема є однією з основних на сьогодні, і для їі подолання необхідно підвищувати рівні професійних компетентностей, зокрема інформатичної компетентності майбутніх педагогів професійного навчання, тобто спрямувати освітній процес ЗВО на більш поглиблене вивчення здобувачами освіти дисциплін інформатичного спрямування, а саме: зміцнення їхніх знань про інформаційну структуру, функціювання та роботу інформаційних систем, а також удосконалення

*C) Базиль C. M.

os 
вмінь та навичок використання засобів IКТ на високому професійному рівні у своєму житті та професійній діяльності.

У межах наукового дослідження відповідно до проблеми ми вважаємо, що для подальшого підвищення рівня сформованості інформатичної компетентності майбутніх спеціалістів, зокрема педагогів професійного навчання, необхідно побудувати педагогічну модель освітнього процесу, проаналізувати й обгрунтувати елементи педагогічної моделі формування інформатичної компетентності майбутніх педагогів професійного навчання в закладах вищої освіти (3ВО).

Аналіз досліджень. Підготовка інформатично грамотних спеціалістів в умовах освітнього процесу професійних закладів освіти базується на компетентнісному підході, основні ідеї якого висвітлювали як закордонні, так і вітчизняні науковці (Є. Зеєр, О. Пометун, А. Хуторський та інші).

Проблемою формування інформатичної компетентності в майбутніх спеціалістів різних профілів навчання опікувалися такі вчені: Н. Баловсяк, В. Болотов, С. Долінський, М. Жалдак, С. Зелінський та інші. У наукових працях про формування інформатичної компетентності майбутніх спеціалістів, зокрема педагогів професійного навчання, було проаналізовано спектр проблем, а також обгрунтовано шляхи їх вирішення.

Важдивими для нашого наукового дослідження $е$ наукові здобутки таких учених: В. Ковальчука, В. Курок, Н. Ничкало, С. Сисоєва та ін., які у опікувалися проблемою модернізації освітнього процесу підготовки педагогів професійного навчання в закладах професійної освіти.

Метою статті є розкриття сутності поняття «педагогічна модель», аналіз й обгрунтування розробленої педагогічної моделі формування інформатичної компетентності майбутніх педагогів професійного навчання в закладах вищої освіти.

Виклад основного матеріалу. Наукове дослідження процесу формування інформатичної компетентності в майбутніх спеціалістів, зокрема педагогів професійного навчання в 3ВО, відбувається в декілька етапів. Одним із таких етапів є моделювання, тобто розробка педагогічної моделі, яка надає можливість відтворити особливості об'єкта дослідження та встановити взаємозв'язки між системними елементами процесу формування.

У сучасному тлумачному словнику української мови поняття «модель» означає зразок якогось нового виробу, взірцевий примірник чогось; зразок, що імітуе будову й дію певного об'єкта. Процес модедювання - створення моделі чогось; дослідження об'єкта, системи, явища, процесу через побудову й вивчення їхніх моделей.

Більшість науковців вважає, що модель - це спрощена схема матеріальної структури відображення факторів, речей, ставлень певної галузі знань. На думку А.Новикова, Д.Новикова, модель - це «спосіб організації практичних зразково правильних дій та їхніх результатів в робочу демонстрацію, образ майбутньої системи» $[8$, с. 43]. Є. Додатко вважає, що модель - це уявний об'єкт, який наділений суттєвими властивостями, що не має незначних ознак, які б відрізняди його від оригіналу [7].

Педагогічна модель показуе взаємозв'язки між елементами досліджуваного процесу і їхню залежність один від одного, а також надае можливість з'ясувати й виокремити важдиві характеристики анадізованого об'єкта і його функціювання. Завдяки процесу моделювання можна визначити сукупність властивостей моделі, тобто відповідно до мети моделі будується їі деталізація. Від визначених цілей залежить вибір особливостей і суттєвих параметрів досліджуваної системи - оригіналу (об'єкта) [9].

У педагогічних дослідженнях сучасності дуже часто використовується моделювання педагогічних процесів. Більшість науковців вважає, що педагогічна модель дозволяе провести аналіз реального об'єкта, відображає і відтворює структуру, характеристики, взаємозв'язки і взаємовідношення між структурними елементами досліджуваного об’єкта. На думку Є. Шматкова, цей підхід виокремдює суттєві ознаки

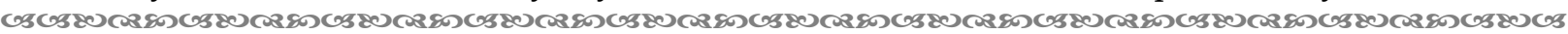


і якості об'єктів, відкидаючи непотрібні, ущільнюе навчальні матеріали, використовуючи графічні зображення, схеми тощо; надає мождивість виявити приховані взаємні зв'язки і відносини, а також може стати засобом формування узагальненого аналізу і синтезу, інструментом організації і пізнавальних процесів, виступати мнемотехнічним засобом [10, с. 50].

На основі педагогічних умов і проведених нами досліджень була розроблена педагогічна модель формування інформатичної компетентності в майбутніх педагогів професійного навчання в ЗВО (рис. 1).

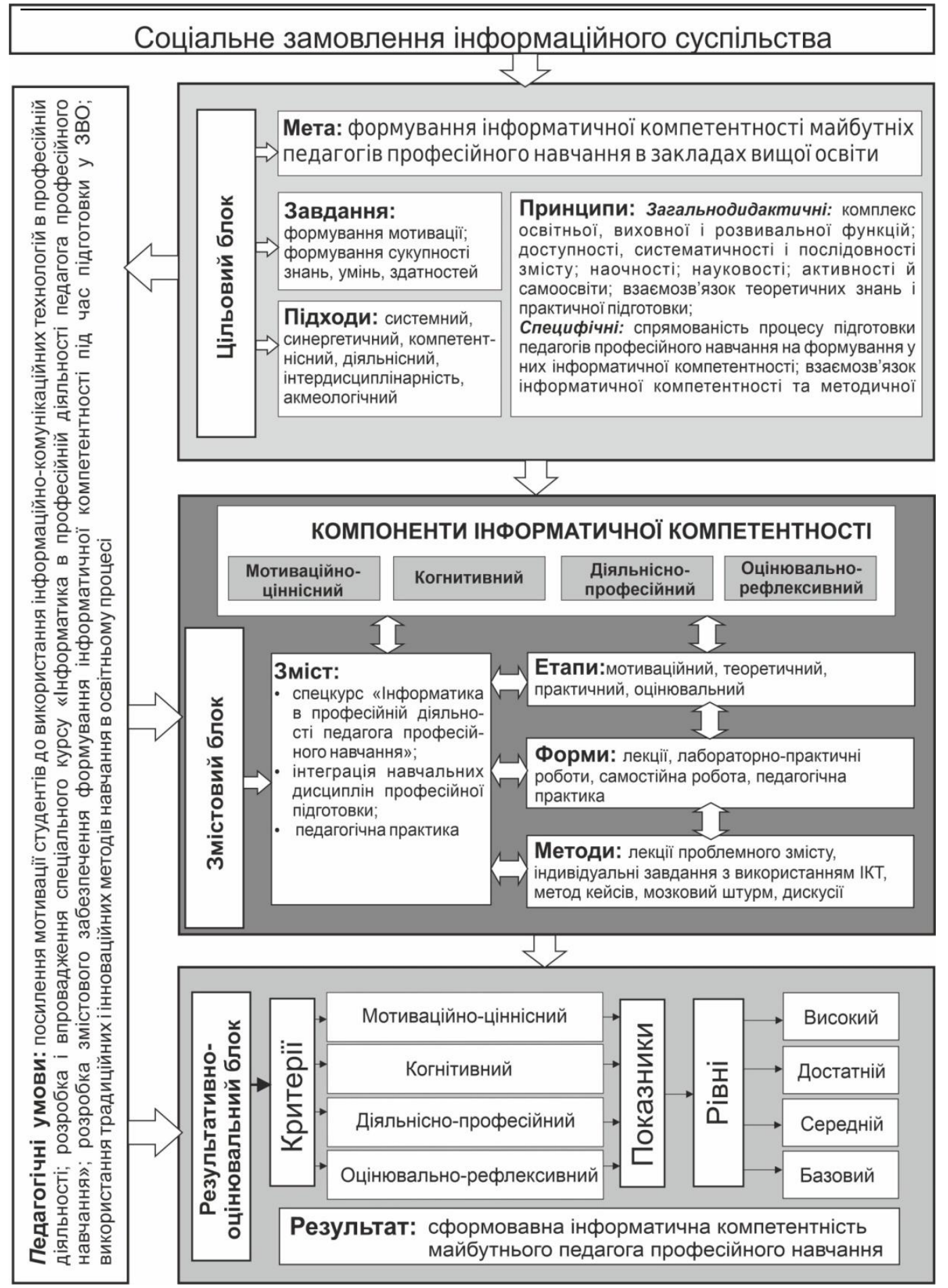

Рис. 1. Педагогічна модель формування інформатичної компетентності в майбутніх педагогів професійного навчання 
Педагогічна модель складається з сукупності блоків, взаємозв'язків, залежностей між ними. До них належать такі блоки: цільовий - містить мету, завдання, підходи й принципи; змістовий - включає компоненти інформатичної компетентності, зміст, етапи, форми і методи навчання; результативно-оцінювальний - включає критерії, показники й рівні, які сприяють отриманню конкретного результату, тобто сформованість інформатичної компетентності майбутніх педагогів професійного навчання.

Мета моделі передбачає формування інформатичної компетентності в майбутніх педагогів професійного навчання в ЗВО. Реалізація цієї мети в освітньому процесі ЗВО забезпечить успішне застосування майбутніми педагогами професійного навчання технічних засобів та IKT під час професійної діяльності, тим самим створюючи умови достатньо високої професійної конкуренції в інформаційному суспільстві.

Успішне досягнення поставленої мети можливе за умови виконання таких завдань: формування мотивації; сукупності знань, умінь і здатностей. Також важливими складовими цільового блоку педагогічної моделі є підходи та принципи, що сприяють успішному й ефективному формуванню інформатичної компетентності в майбутніх педагогів професійного навчання в ЗВО. Отже, на нашу думку, до таких підходів можна віднести системний, синергетичний, компетентнісний, діяльнісний, інтердисциплінарний, акмеологічний.

Системний підхід дуже часто використовуеться в наукових дослідженнях. Особливості системного підходу висвітдювали у своїх роботах багато науковців: В. Абрамов, А. Артюшкіна, В. Беспалько, В. Корбутяк, Н. Сидорук та інші. В. Корбутяк розглядає системний підхід як комплексний аналіз об'єктів і явищ, ураховуючи взаємозв'язки між ними і їхні характеристики [5]. Деякі науковці вважають, що основними завданнями системного підходу є дослідження теоретичної та практичної діяльності й розглядають це дослідження як систему взаємопов'язаних елементів; визначення і аналіз структури, змісту, організації, взаємозв'язків системи; виокремлення основних зовнішніх зв'язків; виявлення закономірностей і тенденцій розвитку системи [1, с. 12-13].

Відповідно до нашого дослідження, системний підхід надає мождивість детадьно проаналізувати внутрішню структуру процесу формування інформатичної компетентності в майбутніх педагогів професійного навчання, виокремити та характеризувати елементи підсистем. Завдяки системному підходу ми розгдядаємо педагогічну діяльність як один із елементів процесу формування інформатичної компетентності в майбутніх педагогів професійного навчання в ЗВО.

Ще одним підходом є синергетичний, який тісно пов'язаний 3 системним підходом і націлює педагогів на реалізацію основних синергетичних ідей: інваріантність (незмінність за певних умов), відкритість, когерентність (взаємодія елементів системи) [6, с. 811]. Завдяки трьом головним ідеям синергетичного підходу система може бути в рівновазі, навіть при певних змінах в структурі та функціях.

Синергетичний підхід базується на фундаментальному принципі, а саме: саморозвитку, тобто здатності особистості до самоорганізації (невід'ємна властивістю особистості (здобувач освіти) в межах синергетичного підходу), самоосвіти, самореалізації завдяки взаємодії з навкодишнім інформаційним середовищем. Отже, синергетичний підхід вимагає від учасників освітнього процесу тісної взаємодії, в основі якої лежить рефлексія, що надає майбутнім спеціалістам розробити власний стиль діяльності, ураховуючи інформатичну складову, а також упровадження ії в професійну діяльність.

У контексті наукового дослідження для дотримання тісної взаємодії між учасниками освітнього процесу, у розрізі синергетичного підходу, на нашу думку, доцільно застосувати інтерактивні й інноваційні методи і прийоми, які потрібні для засвоєння майбутніми педагогами професійного навчання теоретичного матеріалу

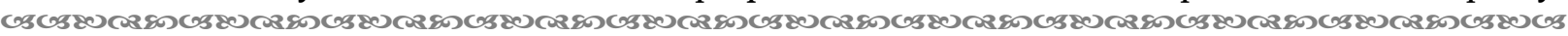


(використання програмного забезпечення, робота 3 інтерактивним і мудьтимедійним обладнанням тощо), а також активного формування інформатичної компетентності, методичних умінь і навичок, самостійний пошук рішень проблемних завдань професійного спрямування.

Цей підхід сприяе непомітно й невимушено залучити здобувача освіти до освітнього процесу на умовах рівноправного учасника, тобто як у ролі здобувача освіти, так і в ролі викладача. Завдяки цьому майбутні педагоги професійного навчання зможуть иегко й швидко опановувати складний матеріал, отримувати певний досвід, який потрібен для подальшої професійної діяльності.

Третім підходом у нашому дослідженні є компетентнісний. У науково-педагогічній літературі дуже часто описується застосування компетентнісного підходу в освітньому процесі закладів освіти, зокрема 3ВО. Проаналізувавши інформаційні джерела, можемо відзначити, що більшість науковців трактуе поняття «компететентнісний підхід» як метод моделювання результатів навчання, що забезпечує автономію в змісті і структурі навчального плану; передбачає вирішення професійних завдань, пов'язаних 3 формуванням інформатичної компетентності, використовуючи IKT, технічні засоби навчання i навчально-методичне забезпечення; формування індивідуальних професійних якостей застосування IKT та технічних засобів навчання; передбачае овододіння комплексом знань, умінь, навичок і готовності до саморозвитку, самоосвіти, самореалізації в професійній діяльності, використовуючи IКТ та технічних заходів навчання $[1 ; 2 ; 6]$.

Четвертим підходом цільового блоку педагогічної моделі формування інформатичної компетентності в майбутніх педагогів професійного навчання є діяльнісний. Він забезпечує безперервний розвиток особистості в морально-етичному, культурному, професійному напрямі відповідно до вимог інформаційного суспільства і стрімкого розвитку в сфері IKT. Цей підхід дозводяе визначати фундаментальні змістово-методологічні підстави освіти; здійснювати формування умінь, досвіду роботи з IКТ і впровадження їх у професійну сферу своєї діяльності.

На думку Н. Брюханової, діяльнісний підхід - це підхід для створення умов для активної діяльності суб'єкта, завдяки чому відбувається засвоєння ним певного навчального матеріалу й отримання досвіду [3]. Науковці зауважують, що впровадження діядьнісного підходу в освітній процес є важдивим для подальшого розвитку компетентностей майбутніх спеціалістів, оскільки саме діяльність $є$ механізмом ефективних особистісних змін. У межах нашого дослідження процес формування інформатичної компетентності в майбутніх педагогів професійного навчання означає організацію й управління освітньою діяльністю здобувачів освіти в контексті запровадження IКТ у свою професійну діяльність; розуміння значущості знань IKT, їх застосування в повсякденному житті і професійній сфері діядьності; залучення здобувачів освіти до практичної діяльності для отримання умінь, навичок та певного досвіду застосування IКТ в освітньому процесі та професійній діяльності.

Ще одним підходом цільового блоку педагогічної моделі є інтердисциплінарний. Інтердисциплінарний підхід- це підхід, в основі якого лежить інтеграція, а саме: інтеграція освітнього процесу і міждисциплінарних зв'язків. За даними сучасного тлумачного словника української мови, інтеграція - це об'єднання чого-небудь у єдине ціле. Одним з інтегрованих елементів інтердисциплінарного підходу є «міжпредметні зв'язки». На думку С. Гончаренко, вони е відображенням комплексного підходу до навчально-виховного процесу, тобто узгодженість навчальних програм, які «зумовлені системою наук i дидактичною метою» [4]. На нашу думку, інтердисциплінарний підхід надає можливість перетворенням усередині педагогічної системи, усе це відбувається завдяки поєднанню теоретичної і практичної підготовки, комплексу знань, умінь, навичок і певного досвіду, а також міждисциплінарних зв'язків. 
Цей підхід об'єднуе знання з інформатичних дисциплін, технічних засобів навчання, IKT, спеціальних дисциплін, методичних умінь і навичок в єдине ціле.

Останнім підходом цільового блоку педагогічної моделі є акмеологічний підхід. Акмеологічний підхід - це процес створення умов для розвитку усіх учасників освітнього процесу, а також надає поняття про успіх, високі досягнення, що потрібні суб'єкту для розвитку особистості. Акмеологічний підхід у ЗВО надає здобувачу освіти мождивість розвиватися як особистість, ураховуючи індивідуальні характеристики; формувати духовні, моральні цінності, професійні здібності, уміння досягати поставлені цілі та вирішувати завдання професійного спрямування.

Формування інформатичної компетентності в майбутніх педагогів професійного навчання в 3 ВО вимагає певної організації освітнього процесу, який грунтується на загальнодидактичних та специфічних принципах навчання. Теоретичний аналіз науково-педагогічної літератури надав мождивість виокремити такі загальнодидактичні принципи навчання: комплекс освітніх, розвивальних і виховних функцій навчання; наочності; науковості; активності і самоосвіти; взаємозв'язку теоретичних знань і практичної підготовки. До специфічних принципів навчання належать спрямованість процесу підготовки педагогів професійного навчання на формування в них інформатичної компетентності; узаємоз'язок інформатичної компетентності та методичної підготовки.

Наступним блоком педагогічної моделі є змістовий. Він включає такі елементи: компоненти інформатичної компетентності (мотиваційно-ціннісний, когнітивний, діяльнісно-професійний, оцінювально-рефлексивний); етапи формування інформатичної компетентності (мотиваційний, теоретичний, практичний, оцінювальний); зміст; форми; методи навчання; педагогічні умови.

Визначення етапів формування інформатичної компетентності в майбутніх педагогів професійного навчання вимагало зробити такі дії: виконати аналіз, з'ясувати та конкретизувати мету.

Першим етапом формування інформатичної компетентності обрали мотиваційний. Основною його метою є формування стійкої позитивної мотивації щодо вивчення інформатичних дисциплін, а також використання IKT у професійній діяльності майбутнього педагога професійного навчання.

Другим етапом формування інформатичної компетентності майбутніх педагогів професійного навчання $\in$ теоретичний. Основною метою якого $є$ оволодіння здобувачами освіти навчального матеріалу інформатичного спрямування, яке відбувається завдяки вивченню таких дисциплін спеціальності 015 Професійна освіта: «Інформатика та комп'ютерна техніка», «Інженерна графіка», «Проєктування швейних виробів», «Комп'ютерна графіка», «Дандшафтний дизайн», «Методика професійної освіти» тощо. На III або IV курсі здобувачі освіти вивчають авторський спецкурс «Інформатика в професійній діяльності педагога професійного навчання», який запроваджений нами в освітній процес з метою об'єднання і доповнення комплексу знань 3 інформатики й IKT, особливостей їх застосування в професійній і педагогічній діядьності.

Третім етапом є практичний, основною метою якого є формування інформатичної компетентності, розвиток умінь і навичок використання IКТ у професійній діяльності, набуття певного досвіду під час виконання комплексу лабораторно-практичних робіт.

Формування певного рівня інформатичної компетентності майбутніх педагогів професійного навчання здійснюеться протягом усього освітнього процесу під час вивчення дисциплін циклу професійної та практичної підготовки, а також за рахунок підготовки здобувачів освіти за програмою авторського спецкурсу.

Четвертим, заключним, етапом формування інформатичної компетентності в майбутніх педагогів професійного навчання є оцінювальний. Основною метою цього етапу є оцінка рівня інформатичної компетентності в майбутніх педагогів професійного

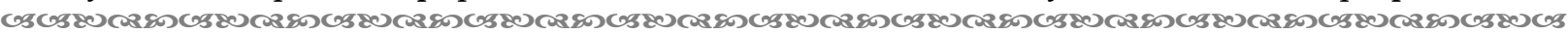


навчання під час занять зі спецкурсу «Інформатика в професійній діяльності педагогів професійного навчання», а також при проходженні навчально-залікової практики. Під час практики здобувачі освіти можуть закріпити, перевірити теоретичні знання, уміння, навички, визначити рівень сформованості інформатичної компетентності. На цьому етапі майбутній педагог професійного навчання осмислює свої педагогічні досягнення, виокремлюе переваги та недоліки, завдяки яким відбувається самокоригування, самовдосконалення щодо формування інформатичної компетентності.

Системоутворюючим елементом змістового блоку педагогічної моделі є зміст етапів формування інформатичної компетентності майбутніх педагогів професійного навчання. Зміст визначає розширення бази теоретичних знань, формує особистісні якості, які потрібні для впровадження і використання IKT; формує методичні уміння і здатності. Структура змісту вкдючає: 1) спецкурс «Інформатика в професійній діяльності педагога професійного навчання»; 2) інтеграція навчальних дисциплін професійної підготовки; 3) педагогічна практика.

Виокремленні нами навчальні дисципліни загального та професійного циклу освітнього процесу так чи інакше впливають на формування інформатичної компетентності в майбутніх педагогів професійного навчання. Вони є одним цілим зі спецкурсом «Інформатика в професійній діяльності педагога професійного навчання», тобто, інтегруючись між собою, доповнюють процес підвищення рівня інформатичної компетентності в майбутніх педагогів професійного навчання.

Аналізуючи розроблену педагогічну модель та враховуючи фундаментальні засади інтерактивного навчання, виділимо такі форми навчання: лекції, лабораторно-практичні роботи, самостійні роботи, педагогічна практика. Серед методів навчання виділено такі: лекції проблемного змісту, індивідуальні завдання з використанням IКТ, метод кейсів, мозковий штурм, дискусії.

Ще одними із основних елементів педагогічної моделі є виокремлені нами педагогічні умови формування інформатичної компетентності в майбутніх педагогів професійного навчання: 1) посилення мотивації здобувачів освіти до використання інформаційно-комунікаційних технологій в професійній діяльності; 2) розробка змістового забезпечення формування інформатичної компетентності під час підготовки у 3ВО; 3) розробка і впровадження спецкурсу; й інноваційних методів навчання в освітньому процесі.

Останнім блоком запропонованої педагогічної моделі є результативно-оцінювальний. У цьому блоці критерії і показники формування інформатичної компетентності в майбутніх педагогів професійного навчання (мотиваційно-ціннісний, когнітивний, діяльнісно-професійний, оцінювальнорефлексивний); рівні сформованості інформатичної компетентності (високий, достатній, середній базовий), а результатом у педагогічній моделі є сформована інформатична компетентність педагогів професійного навчання.

Висновки. Отже, запропонована педагогічна модель є цілком працездатною і спрямована на досягнення конкретного результату. Також вона є поштовхом для подальшого нашого дослідження, тобто кроком для розробки організаційнометодичного забезпечення моделі формування інформатичної компетентності майбутніх педагогів професійного навчання в процесі професійної підготовки в ЗВО.

\section{Список використаних джерел:}

1. Абрамов В. І., Арутюнов В.Х. Метододогія системного підходу та наукових досдіджень: навч.-метод. посіб. для самост. вивч. дисц. Київ: КНЕУ, 2005. 178 с.

2. Бібік Н. М. Компетентнісний підхід: рефлексивний аналіз застосування. Компетентнісний підхід у сучасній освіті: світовий досвід та українські перспективи. Київ: К.I.С., 2004. С. 45-50.

3. Болотов В. А., Сериков В. В. Компетентностная модель: от идеи к образовательной программе. Педагогика. 2003. № 10. С. 8-14.

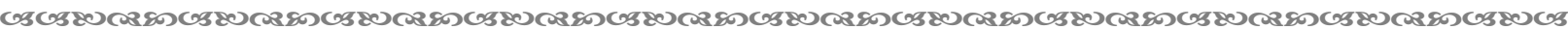


4. Брюханова Н. О. Про діядьнісний підхід до формування змісту підготовки інженернопедагогічних кадрів. Проблеми інженерно-педагогічної освіти: збірник наукових праць. Харків: Українська інженерно-педагогічна академія, 2007. № 17. С. 148-162.

5. Гончаренко С. У. Педагогічні дослідження: методологічні поради мододим науковцям. Київ - Вінниця: ДОВ «Вінниця», 2008. 278 с.

6. Корбутяк В. І. Методологія системного підходу та наукових досліджень: навчальний посібник. Рівне: НУВГП, 2010. 176 с.

7. Кремінь В. Г. Енциклопедія освіти. Київ: Юрінком Інтер, 2008. 1040 с.

8. Лодатко Є. Методологічні засади моделювання соціокудьтурних процесів. Рідна школа. 2008. № 3-4 (939-940). С. 13-19.

9. Новиков А. М., Новиков Д. А. Образовательный проект: методология образовательной деятельности. Москва: «Эгвес», 2004. 120 с.

10. Томашевський В. М. Моделювання систем. Київ: ВНМ, 2005. 352 с.

11. Шматков Е. В., Шматков Д. І. Використання моделювання при навчанні учнів професійнотехнічних навчальних закдадів робітничим професіям. Теорія $i$ практика управління соціальними системами. 2009. № 2. С. 50-54.

\section{References:}

1. Abramov, V. I., \& Arutjunov, V. Kh. (2005). Metodolohiia systemnoho pidkhodu ta naukovykh doslidzhen [Methodology of the systemic approach and scientific researches]. Kyiv: KNEU [in Ukrainian].

2. Bibik, N. M. (2004). Kompetentnisnyi pidkhid: refleksyvnyi analiz zastosuvannia [Competence approach: reflexive analysis of the application]. Kompetentnisnyj pidkhid u suchasnij osviti: svitovyj dosvid ta ukrajinsjki perspektyvy, 45-50 [in Ukrainian].

3. Bolotov, V. A., \& Serykov, V. V. (2003). Kompetentnostnaja model': ot idei k obrazovatel'noj programme [Competent model: from the idea to the educational program]. Pedahohika, 10, 8-14 [in Russian].

4. Briukhanova, N. O. (2007). Pro diialnisnyi pidkhid do formuvannia zmistu pidhotovky inzhenerno-pedahohichnykh kadriv [About the active approach for forming the content of the engineering and pedagogical staff training]. Problemy inzhenerno-pedahohichnoi osvity, 17, 148-152 [in Ukrainian].

5. Honcharenko, S. U. (2008). Pedahohichni doslidzhennia: metodolohichni porady molodym naukovtsiam [Pedagogical researches: Methodological advice for young scientists]. Kyiv - Vinnytsia: DOV "Vinnycja" [in Ukrainian].

6. Korbutiak, V. I. (2010). Metodolohiia systemnoho pidkhodu ta naukovykh doslidzhen [Methodology of the system approach and scientific researches]. Rivne: NUVGhP [in Ukrainian].

7. Kremin, V. H. (2008). Entsyklopediia osvity [Encyclopedia of education]. Kyiv: Yurinkom Inter [in Ukrainian].

8. Lodatko, Ye. (2008). Metodolohichni zasady modeliuvannia sotsiokulturnykh protsesiv [Methodological bases of socio-cultural modelling of processes]. Ridna shkola, 3-4 (939-940), 13-14 [in Ukrainian].

9. Novikov, A. M., \& Novikov, D. A. (2004). Obrazovatel'nyj proekt: metodologija obrazovatel'noj dejatel'nosti [Educational project: educational methodology]. Moscow: "Jegves" [in Russian].

10. Tomashevskyi, V. M. (2005). Modeliuvannia system [Modelling of systems]. Kyiv: VNM [in Ukrainian].

11. Shmatkov, E. V., Shmatkov, D. I. (2009). Vykorystannia modeliuvannia pry navchanni uchniv profesiino-tekhnichnykh navchalnykh zakladiv robitnychym profesiiam [The use of modelling at training students of vocational schools]. Teoriia i praktyka upravlinnia sotsialnymy systemamy, 2, 50-54 [in Ukrainian].

Bazil S. M., orcid.org/0000-0002-9370-9355

\section{THE AUTHOR'S MODEL OF THE FORMATION OF FUTURE PROFESSIONAL TRAINING TEACHERS' INFORMATIVE COMPETENCE}

The paper presents the results of scientific research of the process of formation of informative competence in future specialists, in particular, teachers of professional training in higher education 
institutions, reproduced features of the research object on the example of the developed pedagogical model and established interrelations between the system elements of the process of informative competence formation. The basis of the article is to highlight the opinions of the significant number.

During the analysis of scientific and pedagogical literature the components of the pedagogical model of the formation of future professional training teachers' informative competence were defined and pedagogical conditions and blocks of pedagogical model were singled out. In view of theoretical analysis it is possible to say that pedagogical model has such interconnected blocks: Target - Contains goals, tasks, approaches (systemic, synergistic, competence, active, interdisciplinary, acmeological) and principles (the base of didactic, specific); Semantic -includes the components of informative competence (motivational-axiological, cognitive, active-professional, appraisal-reflexive), content, stages, forms and methods of training; effective-appraisal - includes criteria, indicators and levels that facilitate obtaining of a specific result, i.e. the formation of future professional training teachers' informative competence during the in higher education institutions.

On the basis of the analysis of scientific and pedagogical literature, a pedagogical model was developed, which is quite efficient and aimed at the formation of future professional training teachers' informative competence. It is also an impetus to the development of educational and methodological support and special courses proposed the model of the formation of future professional training teachers' informative competence during the in higher education institutions.

Key words: competence, informative competence, component, model, pedagogical model, education, criteria, higher education, educator of professional training.

Дата надходження статті: 20.01.2020 p. Рецензент: доктор педагогічних наук, доцент Грудинін Б. О.

УДК 378.371.134:37.025.8

DOI https://doi.org/10.37915/pa.vi45.87

Бурчак C. О.,

orcid.org/0000-0002-1641-3251

\section{ХАРАКТЕРИСТИКА МОДЕДІ СИСТЕМИ РОЗВИТКУ ТВОРЧОСТІ МАЙБУТНІХ УЧИТЕЛІВ МАТЕМАТИКИ}

У статті схарактеризовано модель систели розвитку творчості майбутніх учителів математики в процесі фахової підготовки в педагогічному університеті. Висвітлено аналіз працьв сучасних науковців з питань проєктування, моделювання, моделей різноманітних педагогічних процесів. Крім того, представлено детальний опис їі структурних компонентних складників (соціальне замовлення, мета $i$ завдання, методологічний, теоретичний, практичний, результативно-коригувальний компоненти), а також указана умова достатньої узагальненості досліджуваних змістових і структурно-процесуальних ї̈ компонентів, завдяки виконанню якої вона може бути апробованою та реалізованою в реальному освітньому проиесі педагогічних закладів вищої освіти.

Подано основні етапи процесу моделювання системи (осмислення й визначення функцій модельованого об'єкту; побудова максимально функціональної системи наскрізних компонентів структури досліджуваного об'єкту; установлення функціонального, логічного, технологічного, семантичного та інших видів взаємозв'язків між компонентами моделі; вивчення динахіки досліджуваного об'єкту, закономірностей функціонування системи; накопичення відомостей про об'єкт дослідження за допомогою теоретичних та емпіричних методів дослідження).

*(C) Бурчак С. O.

os 